\title{
Turkey's experience with disinflation: where did all the welfare gains go?
}

\section{Bilin Neyapti}

To cite this article: Bilin Neyapti (2013) Turkey's experience with disinflation: where did all the welfare gains go?, Applied Economics Letters, 20:7, 664-668, DOI: 10.1080/13504851.2012.727970

To link to this article: https://doi.org/10.1080/13504851.2012.727970

曲 Published online: 19 Oct 2012.

Submit your article to this journal $\pi$

Џlll Article views: 135 


\title{
Turkey's experience with disinflation: where did all the welfare gains go?
}

\author{
Bilin Neyapti \\ Department of Economics, Bilkent University, Bilkent, Angkara 06800, \\ Turkey \\ E-mail:neyapti@bilkent.edu.tr
}

This article measures the welfare gains from disinflation in Turkey during the 2000s. Estimated welfare gains exceed the real output gains, which is likely to arise from persisting allocative inefficiencies, pointing at the need for further structural and institutional reforms for the benefits of price stability to be utilized towards achieving sustainable development.

Keywords: Turkish inflation; disinflation; welfare costs of inflation

JEL Classification: E31; E41; I31

\section{Introduction}

Inflation leads to welfare losses, commonly known as the shoe-leather and menu costs. When the rate of inflation is high and highly volatile, it redistributes income from the lender to the borrower. Uncertainty in real returns leads to low investment activity and growth, hampering sustainable development. Furthermore, anticipating a reduction in the real value of money, agents have an incentive to defer payments, which increases inefficiencies in tax collection, nonperforming loans and national imbalances.

Turkey experienced high and volatile inflation for three decades since the 1970s (see Fig. A1 in the appendix). ${ }^{1}$ Notwithstanding, the Turkish economy continued to grow, though exhibiting great volatility and at lower than desirable rates for a developing country. Following the banking crisis in 2001, a comprehensive stabilization programme was adopted (see Celasun, 2002). The programme entailed several legal reforms including revisions in the central bank, banking and bankruptcy laws. Increased degree of central bank independence was reinforced by the adoption of, first implicit and then (in 2006) explicit, inflation targeting. These reforms were successful at least by an account of inflation that declined to below $10 \%$ in the second half of the 2000s. The single-party government that dominated the political scene during the 2000s both facilitated the government's decision-making process and benefited, in turn, from the reforms that were followed by a period of notably favourable economic circumstances.

This article presents an original attempt to quantify the size of welfare gain from disinflation in Turkey. While this is a difficult task, it paves the way for further research by presenting striking empirical evidence. The potential implications of the rapid disinflation are contrasted with the post-reform period macroeconomic performance. It is expected that disinflation improves welfare by contributing to growth and sustainable development. Increased demand for liquidity facilitates transactions and enables longer term contracts including investment. Moreover, low inflation is expected to reduce the incentives for deferred tax payments and debt service, and hence to improve macroeconomic balances and efficiency.

However, the evidence on the gains from Turkish disinflation is somewhat mixed. The Turkish economy grew only dismally more per annum during the disinflationary period as compared to the former three

${ }^{1}$ Over the period, the average inflation rate was about $50 \%$, and over the 1980 s and 1990 s, the average was $64 \%$. 
decades (4.59 versus 4.46). ${ }^{2}$ The GINI coefficient has showed only a slight improvement (43 during 1987-2001 versus 40 in 2008). Slight improvements can also be cited with regard to total domestic and FDI (percentage of GDP) and domestic credit growth. However, current account balance (even prior to the great recession), external debt, female labour force participation and gross savings to GDP have all worsened during the 2000s as compared to the earlier decade. Furthermore, annual inflation showed a rising trend after 2007, hitting double digits at times.

The evidence presented in the current study justifies the question 'Where have the welfare gains from disinflation gone?' It aims to provoke further studies that seek answers to it by identifying the inefficiencies in the distribution of the welfare gains. In what follows, the section 'Data and estimation' presents the estimation of money demand and the welfare gains from disinflation. The section 'Calculating the welfare changes' discusses the nature of the welfare gains from inflation. Section III concludes this article.

\section{Measuring the Welfare Gains from Disinflation in Turkey}

Bailey (1956) models real money demand as in Cagan (1956), where real income is relatively stable and nominal interest rate changes can be proxied by inflation expectations:

$$
m_{t}=\left(M_{t}-p_{t}\right)=\alpha+b \pi_{t}^{\mathrm{e}}+\varepsilon_{t}
$$

where $M$ stands for the log of M1 stock, $p$ is the CPI $(1987=100)$ and $\pi_{t}^{\mathrm{e}}$ stands for inflationary expectations. $\alpha$ is a constant and $\varepsilon_{t}$ is the error term. Bailey (1956) argues that as inflation rises, people's real money holdings decline, leading transaction costs to rise and transactions to decrease. As the inflation tax imposed on people is captured by the government as seignorage revenues, the welfare losses associated with a rise in the inflation rate (say, from $\pi_{2}$ to $\pi_{1}$ in Fig. 1) can be shown as the shaded area under the inverse demand curve in Fig. 1. ${ }^{3}$

Metin and Muslu (1999) provide evidence that Cagan's model can be used to explain the inflationary and monetary behaviour in the Turkish economy, where $\pi_{t}^{\mathrm{e}}$ is assumed to be contained in the past

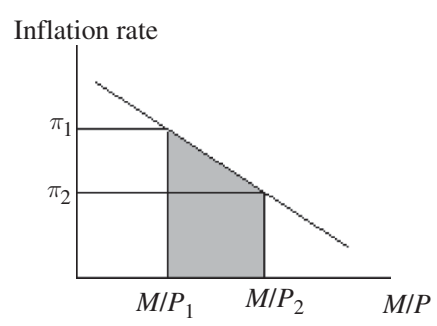

Fig. 1. Welfare loss from inflation

period's inflation rate, because under chronic inflation adaptive expectations can be rational.

\section{Data and estimation}

The data we employ to estimate money demand in Turkey cover the period from 1987:Q1 to 2010:Q4 (source: the Central Bank of the Republic of Turkey (CBRT)). Table 1 provides abbreviations for the series used in the benchmark regression model. The initial step to estimate Equation 1 is to make sure that there is a stable long-term relationship between the variables used in the estimation. To do this, all the series are first deseasonalized using the Tramo-Seats method. ADF and Phillips-Perron (PP) tests confirm the existence of unit roots (see Table 2).

According to Table 2, Inml is nonstationary. CPIinf fails the ADF test but passes the PP test when trend and intercept are employed; however, it passes either tests when only the intercept is employed and hence can be taken as nonstationary. ${ }^{4}$ The table also shows that the first differences are stationary. Hence, the series are $I(1)$. While the null hypothesis of "no cointegration' is rejected based on the Johansens's eigenvalue and Trace tests, the null of 'at most one cointegrating vector' cannot be rejected for either of the variables. ${ }^{5}$ Hence, the OLS estimation of $\operatorname{lnm} 1$ in levels is appropriate.

Table 1. Variables used in the estimation (quarterly, deseasonalized series)

\begin{tabular}{ll}
\hline Abbreviation & Variable descriptions \\
\hline $\ln 11$ & $\begin{array}{c}\text { Natural logarithm of real money balance } \\
(\mathrm{M} 1 / \mathrm{CPI})\end{array}$ \\
$\begin{array}{l}\text { (Inm1) } \\
\text { CPIinf }\end{array}$ & $\begin{array}{c}\text { First difference of } \operatorname{lnm} 1 \\
\text { Natural logarithm of CPI inflation rate }\end{array}$ \\
\hline
\end{tabular}

\footnotetext{
${ }^{2}$ Because of the crisis episodes in both the periods before and after reforms (see Altug et al., 2012, forthcoming), the comparison of the average figures for the two periods is deemed to be fair.

${ }^{3}$ See also Lucas (2000), Serletis and Yavari (2004) and Gupta and Uwilingiye (2008).

${ }^{4}$ CPIinf also passes the ADF test, however, when neither trend nor intercept terms are used, which also support its nonstationarity.

${ }^{5}$ Test results are available from the author upon request.
} 
Table 2. ADF and PP unit root test results

\begin{tabular}{|c|c|c|c|c|}
\hline & \multicolumn{2}{|l|}{$\mathrm{ADF}$} & \multicolumn{2}{|l|}{ PP } \\
\hline & With intercept & With trend and intercept & With intercept & With trend and intercept \\
\hline $\operatorname{lnm} 1$ & 0.85 & -1.53 & 0.85 & -1.53 \\
\hline CPIinf & 0.09 & -4.01 & -1.95 & -4.01 \\
\hline$D(\operatorname{lnm} 1)$ & -8.05 & & -8.05 & \\
\hline$D(C P$ Iinf $)$ & -8.23 & & -14.82 & \\
\hline Critical value $(5 \%)$ & -2.89 & -3.45 & -2.89 & -3.45 \\
\hline
\end{tabular}

Notes: The null hypothesis states that the series has a unit root. PP, Phillips-Perron.

Before proceeding with the estimation, two recent crises must be noted: the 1994 currency crisis that was followed by a severe devaluation and the 2001 banking crisis followed by considerable macroeconomic reforms. These events are controlled by the dummies: $d 94$ and $d 2001$ or by the dummies that stand for the two periods following them: $d 2$ and $d 3 .^{6}$ The possibility of different trends in money holding behaviour is also considered. Hence, the following equation represents the regression model:

$\operatorname{lnm} 1_{t}=\mathrm{f}\left(d 2 ; d 3 ; d 94 ; d 2001 ;\right.$ trend $\left.; C P \operatorname{Iinf}_{t-1} ; \operatorname{lnm} 1_{t-1}\right)$

The last term in the expression is employed to eliminate the serial correlation from the error term. The following regression is selected as parsimonious:

$$
\begin{gathered}
\operatorname{lnm} 1_{t}=0.68-0.039 \text { CPIinf } f_{t-1}+0.93 \operatorname{lnm}_{t-1} \\
(2.31)^{* *}-(3.27)^{* * *} \quad(29.4)^{* * *} \\
\bar{R}^{2}=0.98 ; N=95 ; D W=1.98 ; \delta=0.056 ; \\
\text { Jarque }- \text { Bera }(\text { Normality })=2.82(p=0.24) \\
\text { CHOW }(1994)=0.55(p=0.65) ; \\
\text { CHOW }(2001)=1.26(p=0.29)
\end{gathered}
$$

where the numbers in parentheses under coefficients are the $t$-ratios, $* *$ indicates significance at the $5 \%$ level and $* * *$ indicates significance at the $1 \%$ level. The estimation passes the usual diagnostics as shown (followed by probability values).

$$
\begin{aligned}
{ }^{6} \text { where } d 2 & =\left\{\begin{array}{ll}
1 & \text { if } t \in[1994: 2,2001: 1] \\
0 & \text { otherwise }
\end{array}\right. \text { and } \\
d 3 & = \begin{cases}1 & \text { if } t \in[2001: 2,2010: 4] \\
0 & \text { otherwise }\end{cases}
\end{aligned}
$$

${ }^{7} \ln y$ is the log of quarterly real GDP series (source: CBRT).
Although the Chow tests for 1994 and 2001 indicate no significant structural break, we consider that it is useful to analyse the wealth changes in the three subperiods. The unexpected positive relationship between M1 and inflation in the period between the two economic crises (1994:2 to 2000:4) reflects two related phenomena: first, while inflation fell, it still remained high during this period, leading to substitution from M1 into M2, given the high real interest rates and the short-term nature of term deposits. Similarly, hot money flows led to an increase in M2Y.

\section{Calculating the welfare changes}

To calculate the welfare changes, the differences between the beginning and the end of each subperiod of the estimated $\operatorname{lnm} 1$ series are multiplied by the average of the corresponding CPIinf(-1) figures. This gives the area of the trapezoid depicted in Fig. 1. To develop an economically viable measurement, the same height (the average of the period - beginning and end values of CPIinf) is multiplied with the change in lny for each period. ${ }^{7}$ Taking the ratio of these two areas gives the measurement of the welfare gain with reference to income growth. The resulting number is free of scale and generates an ordinal measurement of welfare gain; call this the Index of Welfare Change (IWC):

$$
\begin{aligned}
I W C= & D(C P \operatorname{Iinf}) \times d\left(\operatorname{lnm} 1_{t}\right) / D(C P \operatorname{Iinf})_{t} \times d\left(\ln y_{t}\right) \\
& =D\left(\operatorname{lnm} 1_{t}\right) / d\left(\ln y_{t}\right)
\end{aligned}
$$

where $D$ refers to the change over the three time periods considered for the estimation: 1987:1 to 1994:1; 1994:2 to 2000:4 and 2001:1 to 2010:4. 
Table 3. Calculating $I W C$

\begin{tabular}{lcrcr}
\hline \multicolumn{5}{l}{ Change in } \\
& \multicolumn{1}{l}{ CPIinf $(\%)$} & $\operatorname{lnm} 1$ & $\ln y$ & \multicolumn{1}{l}{ IWC } \\
\hline 1987:1 to $1994: 1$ & 11.91 & -0.21 & 0.33 & -0.64 \\
$1994: 2$ to $2000: 4$ & -30.58 & -0.04 & 0.41 & -0.09 \\
$2001: 1$ to $2010: 4$ & -5.60 & 0.97 & 0.64 & 1.51 \\
\hline
\end{tabular}

As shown in Table 3, the first period is associated with a welfare loss, equivalent to $64 \%$ of the real GDP growth over that period, as the inflation rate increases (from an annual average of $38.5 \%$ to $104 \%$ ). Hence, assuming that the welfare gains can be proxied by the real GDP growth, one could conjecture that, had the inflation not risen, there could have been about $50 \%$, instead of $31 \%$, cumulative growth over those 7 years (this means $6 \%$ compared to $4 \%$ per annum). The next period, 1994 to 2001 , is associated with a decrease in the inflation rate (from $104 \%$ to $53.5 \%$ ) that is nonetheless associated with 9\% GDP loss.

During the 2000s, the effects of the institutional reforms manifest in a sharper decrease in the inflation rate (from $53 \%$ to $8.6 \%$ per annum) than the previous subperiod, associated with more than $151 \%$ of the output increase in that period. While real GDP increased by about $54 \%$ over the first decade of the $2000 \mathrm{~s}$ ( $4.6 \%$ annual average), the observed welfare gain due to disinflation alone indicates a $81 \%$ rise in real GDP during that period. This implies that the Turkish economy would have grown $11.6 \%$ per annum during the 2000s had the economy internalized these welfare gains. Note that the welfare gain estimates do not include the ordinary growth effects of technological progress and capital accumulation that averages to more than $4 \%$ per annum. ${ }^{8}$

\section{Alternative specifications}

In view of potential biases in estimating the cointegrated series using OLS (see, e.g. Phillips, 1995), the Fully Modified OLS (FMOLS) estimation method is employed to allow for the heterogeneity in the cointegrating vector. FMOLS modifies the estimation to account for serial correlation and for the endogeneity in the regressors resulting from potential cointegrating links. In order to eliminate further possible biases in estimation, forecasts of CPIinf (indicated by CPIinf ${ }^{2}$ ) are obtained by an autoregressive model that takes
Table 4. IWC across different specifications

\begin{tabular}{|c|c|c|c|c|}
\hline \multirow[b]{2}{*}{ Dependent variable } & \multicolumn{2}{|c|}{ CPIinf } & \multicolumn{2}{|c|}{ CPIinf } \\
\hline & OLS & FMOLS & OLS & FMOLS \\
\hline \multicolumn{5}{|l|}{$\operatorname{lnm} 1$} \\
\hline $1987: 1$ to $1994: 1$ & -0.64 & -2.37 & -0.96 & -2.25 \\
\hline $1994: 2$ to $2000: 4$ & -0.09 & 1.82 & 0.05 & 1.73 \\
\hline $2001: 1$ to $2010: 4$ & 1.51 & 0.92 & 1.68 & 0.88 \\
\hline
\end{tabular}

Note: FMOLS, Fully Modified OLS.

into account the trend and period dummies. Table 4 reports the values of $I W C$ resulting from the OLS and FMOLS estimations of Equation 2 using these variables alternatively.

Table 4 provides robustness checks for the results reported in Table 3 (the first column in Table 4) in two dimensions: first, representing inflation expectations by CPIinf $f^{e}$ confirms that the welfare gain of disinflation during the 2000s is more than 1.5-fold of the real GDP growth during the period (1.68). Using this variable, instead of a welfare loss of the magnitude of $9 \%$ of output growth, one observes a welfare gain of about $5 \%$ of growth in the second period. On the other hand, using CPIinf ${ }^{e}$ yields higher $I W C$ values (in absolute value) than CPIinf, indicating a loss of about as much as the gain resulting from the output growth recorded in that period (0.96). Overall, using CPIinf $f^{e}$ to estimate $I W C$ seems to yield slightly greater $I W C$ values. Second, comparing IWC across the OLS and FMOLS estimates reveals several differences: first, according to the FMOLS estimates, disinflation in the 1990s has led to notable welfare gains as well. On the other hand, the estimation results of FMOLS indicate less welfare gains from disinflation in the third period and more welfare losses in the first period.

Focusing on the last decade, the range of the $I W C$ values obtained by all types of estimates is quite notable: the welfare gain from disinflation has been in the range of $88-168 \%$ of the cumulative output growth during that period. This implies that the addition to the trend annual growth should have been between 8.7 and 12.3 had the welfare gains been internalized.

In addition to the above benchmark estimates, the conventional specification of money demand, including the nominal interest rate $(\ln R)$ and real income level $(\operatorname{lny}),{ }^{9}$ is also examined. Both the OLS and FMOLS estimates yield even higher $I W C$ values of 3.05 and 2.27 , respectively. ${ }^{10}$ In conclusion, it is possible to

${ }^{8}$ Given this, one could conjecture that the Per Capita GDP (PPP) would have been about 24000 USD, instead of 15000 USD, in 2010 .

${ }^{9}$ Even though not cointegrated individually, the null of cointegratedness cannot be rejected for the regression relationship between $\ln R$, lny and $\operatorname{lnm} 1$.

${ }^{10}$ Estimates are available from the author upon request. 
claim based on the above range of estimates that, had the welfare gains from disinflation were internalized effectively, the Turkish real GDP would have more than doubled over the past 10 years.

\section{Conclusion}

Following three decades of chronic high inflation experience, Turkey underwent an exemplary case of disinflation during the 2000s. Using Bailey's methodology, this article presents an original measurement of the welfare gains from disinflation $(I W C)$ during this period. $I W C$ estimates indicate that the Turkish economy would have benefited largely from increased price stability, although the economic development observed during the period does not verify that these gains were fully captured. This means that further structural and policy reforms are still needed to reduce the allocational inefficiencies and to achieve sustainable development in Turkey.

\section{Acknowledgements}

I am grateful to Hasan Ersel, Fatih Ozatay, Kivilcim Metin-Ozcan and Taner Yigit for their valuable com- ments and suggestions. Mustafa Kiraci worked on an earlier version of this article as a masters thesis under the author's supervision.

\section{References}

Altug, S., Emin, M. and Neyapti, B. (2012, forthcoming) Institutions and business cycles, International Finance.

Bailey, M. J. (1956) The welfare cost of inflationary finance, Journal of Political Economy, 64, 93-110.

Cagan, P. (1956) The monetary dynamics of hyperinflation, in Studies in the Quantity Theory of Money, (Ed.) M. Friedman, University of Chicago Press, Chicago, pp. 25-117.

Celasun, M. (2002) 2001 Krizi, Öncesi Ve Sonrasi: Makroekonomik ve Mali Bir Değerlendirme, manuscript.

Gupta, R. and Uwilingiye, J. (2008) Measuring the welfare cost of inflation in South Africa, South African Journal of Economics, 76, 16-25.

Lucas Jr, R. E. (2000) Inflation and welfare, Econometrica, 68, 247-74.

Metin, K. and Muslu, I. (1999) Money demand, the Cagan model, testing rational expectations vs adaptive expectations: the case of Turkey, Empirical Economics, 24, 415-26.

Phillips, P. C. B. (1995) Fully modified least squares and vector autoregression, Econometrica, 63, 1023-78.

Serletis, A. and Yavari, K. (2004) The welfare cost of inflation in Canada and the United States, Economic Letters, 84, 199-204.

\section{Appendix}

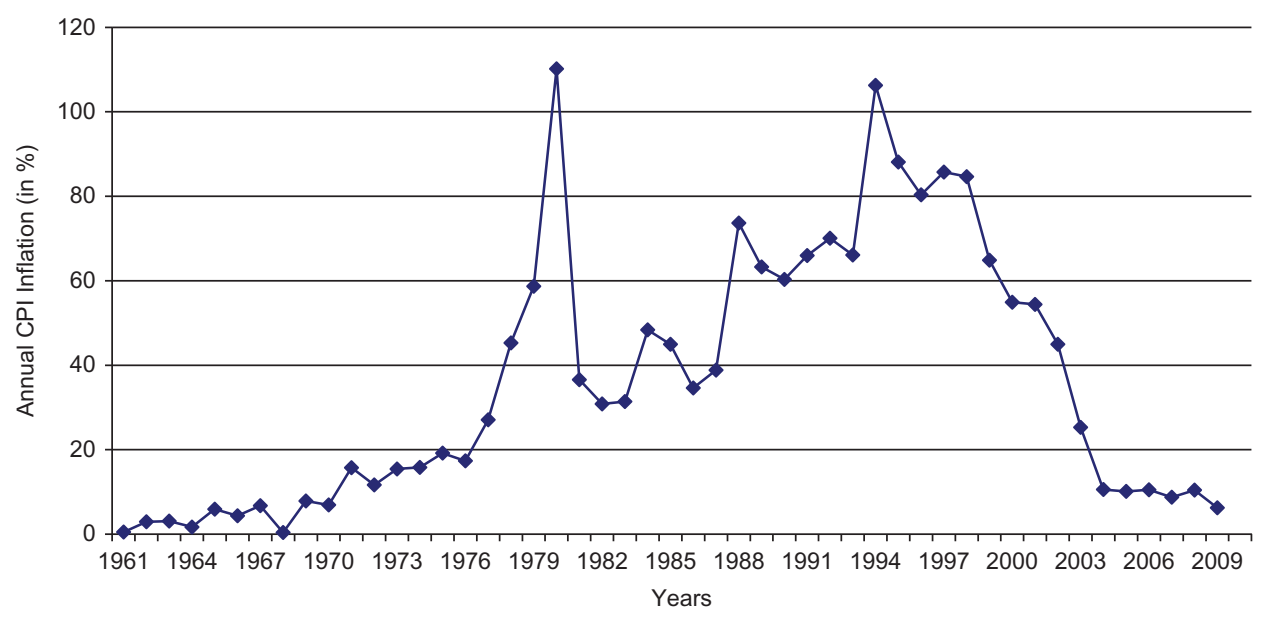

Fig. A1. CPI inflation in Turkey: 1961-2009 